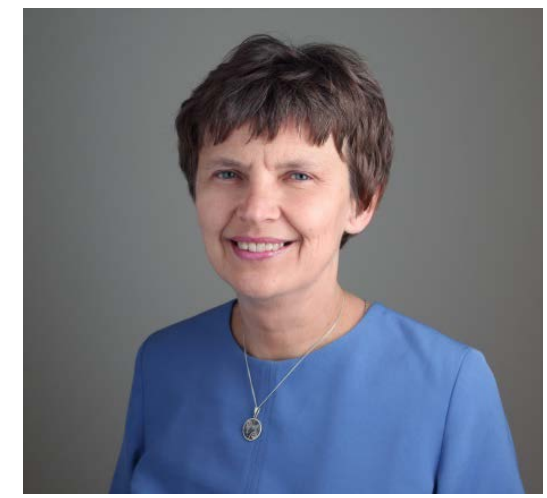

Zaiga Krisjane,

Dr Geography

Professor of the Department

of Human Geography,

Faculty of Geography and Earth Sciences,

University of Latvia

Riga, Latvia

zaiga.krisjane@lu.lv

Co-authors: Janis Krumins, Maris Berzins, Toms Skadins, Guido Sechi, Elina Apsite-Berina

DOI 10.31554/978-5-7925-0571-1-2019-2-162-165

\title{
AGEING CORE-CITY AND REJUVENATED SUBURBIA: EVIDENCE FROM RIGA, 2000-2016
}

Ageing process is a common feature for numerous post-socialist cities in Central and Eastern Europe; whilst suburban areas have displayed a pattern of rejuvenation. Previous research has stressed that the age structure changes in population of postsocialist cities and suburbs are mostly suburbanisation-driven. The aim of the study is to explore spatial and temporal patterns of population structure in Riga and it's metropolitan area. The study analyses 2000 and 2011 Census, as well as 2016 Population register data to provide an overview of residential patterns and geographic trends of the most mobile age group (25-34 years) and the least mobile (65+ years). Our results show that there is residential clusterisation in Riga and its metropolitan areas leading to residential (demographic) polarisation.

Keywords: post-Soviet suburbanization, age structure, ageing, residential (demographic) polarisation, urban decline.

One of the main challenges for urban and regional development in Central Eastern Europe (CEE) are related to the consequences of demographic change [Haase et al. 2011; Kabisch, Haase 2011; Kulcsak, Brown 2017; Fihel, Okólski 2019]. Numerous studies have shown that demographic transition, ageing, fertility behaviour, diversified household structures have a significant implication on urban shrinkage, regional labour and housing market [Buzar et al. 2005; Steinführe, Haase 2007; Botev 2012; Kurek et al. 
2017, Kurek, Wojtowicz 2018, Kazimierczak, Szafrańska 2019]. Many studies on urban shrinkage and post-socialist transition usually conclude that these aspects have complex interlinkages [Couch et al. 2012]. The concept of multiple transformations can be used as a way of explaining the postsocialist urban transition, especially temporal and spatial dynamics of demographic change and its implications on policy, planning and regional development [Sýkora, Bouzarovski 2012; Rink et al. 2014] Similar to other CEE countries, in Latvia suburban development has contributed to demographic differences between metropolitan and non-metropolitan regions. Current demographic trends have raised the concern that an ageing population may increase demographic polarisation at both local and regional level.

Therefore, the aim of the study was to explore spatial and temporal patterns of population structure in Riga and its metropolitan area. Our research focused on evaluating change in the age structure of territorial units of Riga metropolitan area in order to determine the areas that have been characterised by ageing or rejuvenation trends since 2000 .

The study analyses $1 \mathrm{~km}^{2}$ geocoded grid data derived from 2000 and 2011 Census, as well as 2016 Population register to provide an overview of location patterns and trends in the geographies of the most mobile (25-34) and the least mobile (65+) age groups. We utilize Hot spot analysis (GetisOrd $\mathrm{Gi}^{*}$ ), in order to locate clusters of hot and cold spots, of particular age groups and to assess their spatial extent at the national and regional level by conducting an exploratory space-time data analysis [Getis, Ord 1992, 1996; Goodwin, Schoby 2014; Gregory, Patuelli 2015]. This frequently used point pattern analysis method shows where features with either high or low values cluster spatially.

Results showed evidence of a different age composition and development patterns within the capital and its metropolitan area. Urban sprawl, greenfield development; in-fill development; coastal gentrification lead to an increase of younger residents. Hotspots of youth are evident in the urban core of Riga. This can be described as a process of re-urbanization for some neighbourhoods. Other parts of Riga have witnessed an increase of elderly population, which is especially evident in the Soviet panel housing estates. From 2000 to 2016, the population of Riga decreased by $15 \%$ [CSB LV 2019]. Some of them became suburbanites. However, the demographic ageing is much more evident in the peripheral parts of suburbia. Our results show that for the most mobile group, hotspots were evident not only in the 
vicinity of Riga, but also in the urban core of the capital. Overall, an increased residential clusterisation in Riga and its metropolitan areas was observed leading to residential (demographic) polarisation.

\section{References and sources}

Botev N. Population ageing in Central and Eastern Europe and its demographic and social context // European Journal of Ageing. - 2012. - № (90) 2. - P. 69-79.

Buzar S., Ogden P., Hall R. Households matter: The quiet demography of urban trans-formation // Progress in Human Geography - 2005. - № (29)4. - P. 413-436.

Central Statistical Bureau of Latvia (CSB LV) ISG020. Population number and its change by statistical region, city, town and county. - 2019.

Couch C., Cocks M., Bernt M., Grossmann K., Haase A., Rink. D. Shrinking Cities in Europe // Town \& Country Planning. - 2012. - № (81)6. - P. 264-270.

Fihel A., Okólski M. Population Sociétés. - 2019. - № 567. - URL: www.ined.fr.

Getis A., Ord J. K. Local spatial statistics: an overview // Spatial analysis: Modelling in a GIS environment // ed. by P. Longley, M. Batty. - New York: John Wiley \& Sons, 1996. - P. 261-282.

Getis A., Ord J. K. The analysis of spatial association by use of distance statistics // European Geographical Analysis. - 1992. - № (24)3. - P. 189-206.

Goodwin G.C., Schoby J., Council W. A Hot Spot Analysis of Teenage Crashes: An Assessment of Crashes in Houston, Texas. - TX: Texas Southern University, 2014. - 33 p.

Gregory T., Patuelli R. Demographic ageing and the polarization of regions - an exploratory space-time analysis // Environment and Planning A - 2015.- № (47)5. P. 1192-1210.

Haase A., Steinführer A., Kabisch S., Grossmann K., Hall R. (eds.). Residential change and demographic challenge: the inner city of East Central Europe in the 21st century. - Farnham: Ashgate Publishing, 2011. - 376 p.

Kabisch N., Haase D. Diversifying European agglomerations: evidence of urban population trends for the 21st century // Population, space and place. - 2011. № (17)3. - P. 236-253.

Kazimierczak J., Szafrańska E. Demographic and morphological shrinkage of urban neighbourhoods in a post-socialist city: the case of Łódź, Poland // Geografiska Annaler: Series B, Human Geography. - 2019.- № (101)2 - P. 138-163.

Kulcsar L., Brown D. Population Ageing in Eastern Europe: Toward a Coupled Micro-Macro Framework // Regional Statistics. - 2017. - № 7 - P. 115-134.

Kurek S., Wojtowicz M. Reurbanisation in a post-socialist city: spatial differentiation of the population in the Kraków Area (Poland) // Geographia Polonica. 2018. - № (91)4. - P. 449-468. 
Kurek S., Wojtowicz M., Gałka J.. Does suburbanisation contribute to the rejuvenation of a metropolitan area? Changes in the age structure of the Kraków metropolitan area in Poland in the light of recent suburbanization // Geographia Polonica. - 2017. - № (90)2. - P. 59-70.

Rink D., Couch C., Haase A., Krzysztofik R., Nadolu B., Rumpel P. The governance of urban shrinkage in cities of post-socialist of a metropolitan area? Europe: policies, strategies and actors // Urban Research \& Practice. - 2014. - № (7) 3 P. 258-277.

Steinführer A., Haase A. Demographic change as future challenge for cities in East Central Europe // Geografiska Annaler: Series B, Human Geography. - 2007. № (89)2. - P. 183-195.

Sýkora L., Bouzarovski S. Multiple transformations: Conceptualising the postcommunist urban transition // Urban Studies. - 2012. - № (49)1. - P. 43-60. 